Erratum

\title{
The case for a foundational materialism: going beyond historical materialist IPE in order to strengthen it.
}

\author{
Ian Bruff
}

Journal of International Relations and Development (2011) 14, 536.

doi:10.1057/jird.2011.16

Correction to: Journal of International Relations and Development (2011) 14, 391-399. doi:10.1057/jird.2011.10

In the above article the heading on page 394 should read as follows:

'Wager II: ideas and culture can be studied only through an acknowledgement of wager I'.

Please note the author biography was incorrect and should read as follows:

Ian Bruff is lecturer in European and International Politics in the School of Social Sciences at the University of Manchester, UK. He is the coordinator of the Critical Political Economy Research Network of the European Sociological Association, and has published widely on European varieties of capitalism, globalisation and social (especially historical materialist) theory. His book Culture and Consensus in European Varieties of Capitalism: A 'Common Sense' Analysis was published by Palgrave Macmillan in 2008. 